\title{
Comparison of the Effects of On-Pump and Off-Pump Techniques on the Quality of Life in Coronary Artery Bypass Surgery
}

\section{Koroner Arter Baypas Cerrahisinde On-Pump ve Off-Pump Tekniklerinin Yaşam Kalitesi Üzerine Etkisinin Karşılaştırılması}

\author{
Nofel Ahmet Binicier ${ }^{1} \oplus$, Atıf Yolgosteren ${ }^{2} \oplus$, Murat Bicer $^{2} \odot$
}

${ }^{1}$ Bursa City Hospital, Bursa, Turkey

${ }^{2}$ Uludağ University Faculty Of Medicine, Bursa, Turkey

Received: 08.09.2020 / Accepted: 14.10.2020 / Published Online: 29.12.2020

Cite as: Binicier NA, Yolgosteren A, Bicer M. Comparıson of the effects of on-pump and off-pump technıques on the qualıty of lıfe in coronary artery bypass surgery Med J Bakirkoy 2020;16(4):374-8

\section{ABSTRACT}

Objective: In this study, we aimed to compare the effects between on-pump and off-pump coronary artery bypass surgery on the effect of quality of life.

Methods: Fifty patients who underwent isolated coronary artery bypass (CABG) between 01.08.2012 - 31.01.2013 were divided into two equal groups (group 1: off-pump CABG; group 2: on-pump CABG). The quality of life of all patients was evaluated using the SF-36 questionnaire in the postoperative first week and first month (8 basic parameters in SF-36 questionnaire form: Physical function, pain, physical role, mental health, emotional role, social function, fitness / fatigue, general health)

Results: One week after CABG surgery, physical function, physical role, social function and emotional role were significantly better in group 1 than group $2(p<0.05)$. There was no statistically significant difference between the two groups in terms of quality of life, one month after $C A B G$ surgery $(p>0.05)$. Physical function was significantly better in female gender one week after CABG $(p<0.05)$. There was no difference between the two genders in terms of quality of life after one month ( $p>0.05)$.

Conclusion: We think that CABG performed off-pump in order to avoid from negative effects of cardiopulmonary bypass has no significant effect on the quality of life of the patients in the postoperative period. Nevertheless, in order to get a clearer idea on this issue, we think that large series studies should be conducted with a higher number of patients.

Keywords: coronary artery bypass surgery, life quality, SF-36 form

öz

Amaç: Bu çalışmada çalışan kalpte yapılan koroner arter bypass (off-pump) ile kardiyopulmoner bypass altında yapılan koroner arter baypasın (on-pump) yaşam kalitesi üzerine etkisini karşılaştırmayı amaçladık.

Metod: Bu çalışmada 01.08.2012 - 31.01.2013 tarihleri arasında izole koroner arter bypas (KABG) yapılan 50 hasta, iki eşit gruba ayrılarak çalışmaya alındı (grup 1: off-pump KABG; grup 2: on-pump KABG). Grupların yaşam kalitesi SF-36 anket formu kullanılarak KABG ameliyatından 1 hafta ve 1 ay sonra değerlendirildi (SF-36 anket formunda ki 8 temel parametre: Fiziksel fonksiyon, ağrı, fiziksel rol, mental sağlık, emosyonel rol, sosyal fonksiyon, zindelik/yorgunluk, genel sağlık).

Bulgular: KABG ameliyatından 1 hafta sonra grup 1'de fiziksel fonksiyon, fiziksel rol, sosyal fonksiyon ve emosyonel rol grup 2'den anlamlı olarak daha iyiydi (p<0.05). 1 ay sonra yaşam kaliteleri açısından iki grup arasında istatistiksel olarak fark bulunmadı ( $p>0.05)$. KABG'den 1 hafta sonra fiziksel fonksiyon kadın cinsiyetinde anlamlı olarak daha iyiydi ( $p<0.05)$. 1 ay sonra yaşam kalitesi açısından iki cinsiyet arasında fark bulunmadı ( $p>0.05)$.

Sonuç: Kardiyopulmoner baypas'ın olumsuz etkilerinden kaçınmak için çalışan kalpte yapılan koroner arter baypasın postoperatif dönemde hastaların yaşam kalitelerinin iyileşmesinde anlamlı bir katkısının olmadığını düşünüyoruz. Yine de bu konuda daha net fikir elde edebilmek için hasta sayısının çok daha fazla olduğu geniş serili çalışmaların yapılması gerektiğini düşünüyoruz.

Anahtar kelimeler: Koroner arter baypas cerrahisi, yaşam kalitesi, SF-36 formu

Corresponding Author:

atif@uludag.edu.tr
N.A. Binicier 0000-0001-8857-2596

A. Yolgösteren 0000-0002-4467-3915
M. Bicer 0000-0002-9011-2609

(c) Telif hakkı Sağlık Bilimleri Üniversitesi Bakırköy Dr. Sadi Konuk Eğitim ve Araştırma Hastanesi'ne aittir. Logos Tıp Yayıncılık tarafindan yayınlanmaktadır. Bu dergide yayınlanan bütün makaleler Creative Commons Atff-GayriTicari 4.0 Uluslararası Lisansı ile lisanslanmıştır.

(c) Copyright Health Sciences University Bakırköy Sadi Konuk Training and Research Hospital. This journal published by Logos Medical Publishing. Licenced by Creative Commons Attribution-NonCommercial 4.0 International (CC BY) 


\section{INTRODUCTION}

Coronary artery disease (CAD) is one of the important diseases affecting the quality of life and one of the most preferred treatment methods is coronary artery bypass (CABG) surgery ${ }^{(1)}$. Currently, coronary bypass surgeries are still commonly performed with traditional sternotomy by using cardiopulmonary bypass (on-pump) or with the beating heart technique without using cardiopulmonary bypass (off-pump).

On-pump CABG has become the preferred treatment method for patients with multiple vascular diseases. On-pump CABG is both safe and effective. However, the use of cardiopulmonary bypass causes many undesirable side effects ${ }^{(2)}$. This affects the quality of life after the operation.

In recent years, off-pump CABG has been the focus of attention. The aim of off-pump CABG is to refrain from cardiopulmonary bypass completely and to avoid the side effects it will cause ${ }^{(3)}$. This surgical technique is thought to improve the postoperative quality of life of the patients.

Although there are many publications in the literature comparing off-pump and on-pump CABG methods in terms of mortality and morbidity, there are few studies comparing these two surgical techniques in terms of quality of life. In this study, we aimed to prospectively compare the effects of on-pump CABG and off-pump CABG surgery on quality of life.

\section{MATERIAL and METHODS}

Approval was obtained from Uludağ University Medical Research Ethics Committee for our study (approval number: 2012-17/6). Fifty patients who underwent isolated CABG operations in Uludağ University Medical Faculty Cardiovascular Surgery Clinic between 01.08.2012-31.01.2013 were included in the study.

Literate and ambulatory patients under 80 years of age who had ejection fraction over $30 \%$, without valve disease, and underwent elective coronary bypass surgery were included in this study. Illiterate nonambulatory patients older than 80 years of age with an additional valvular disease, and an ejection fraction of less than $30 \%$, who were urgently operated were excluded from the study. Patients were divided into 2 groups, as those undergoing off-pump ( $n=25$ :Group 1 ) or on-pump CABG ( $n=25$ : Group 2)

The quality of life of the patients was evaluated by using the SF-36 questionnaire in the first postoperative week and the first postoperative month. SF-36, also known as Short Form 36, is a quality of life questionnaire developed by the Rand Corporation in $1992{ }^{(4)}$. The reliability and validity studies of the Turkish version of SF-36 were conducted by Koçyigit, et al. ${ }^{(5)}$. The SF-36 test also provides important information on patients undergoing cardiac surgery ${ }^{(6)}$. The SF-36 evaluates the person's quality of life with eight sub-parameters:

- Physical function (10 question)

- Pain (2 question)

- Physical role (4 question)

- Mental health (5 question)

- Emotional role (3 question)

- Social function (2 question)

- Fitness/fatigue (4 question)

- General health (5 question)

SF-36 scale provides self-assessment. The scores range from 0 to 100, separately for each subscale. The higher the scores, the higher the quality of life.

\section{Statistical Analysis}

In the statistical analysis of the data, the SF-36 scale scores were expressed as median (minimum-maximum) values. Scale reliability was examined with the Cronbach alpha coefficient. In the intergroup comparisons of subscale total scores, the differences in the scores obtained at the end of the first month relative to the scores of the first week were calculated and the difference scores obtained were compared using the Mann-Whitney test. The Wilcoxon rank sum test was used for within-group comparisons. Analyses of the study were made using the SPSS 20.0 program and $p<0.05$ was considered statistically significant.

\section{RESULTS}

Fifty patients were included in the study. Nine female and 16 male patients underwent on-pump CABG surgery in Group 1 and 3 female and 22 male patients in Group 2 had off-pump CABG surgery. No statisticaly significant difference was present between both groups in terms of comorbidity and age ( $p>0.05)$. 
In Group 1, one week after surgery, physical function, physical role, social function and emotional role were significantly better than in Group $2(p<0.05)$. There was no significant difference between the two groups in terms of pain, general health, mental health and fitness / fatigue ( $p>0.05$ ) (Table-1 and Figure-1).

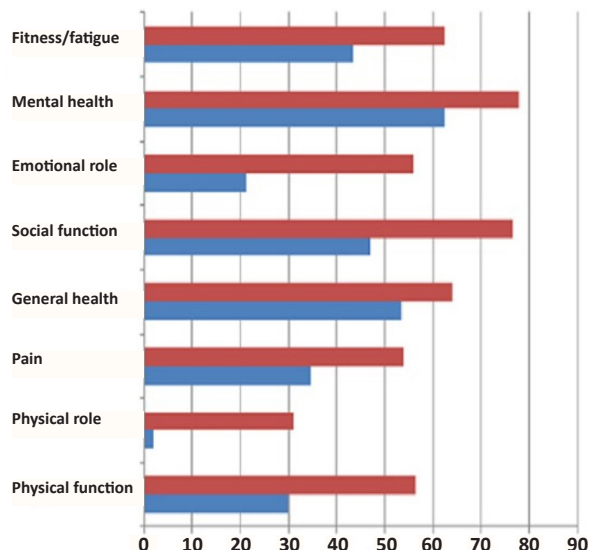

IOff pump CABG IOn pump CABG

Figure 1. Comparison of the quality of life of the off-pump CABG group and the on-pump CABG group one week after surgery.

In Group 1, one month after surgery, physical role was significantly better than in Group $2(p<0.05)$. There was no significant difference between the two groups in terms of social function, emotional role, mental health, fitness / fatigue, physical function, pain and general health (Table-1).
In the first postoperative week, the female gender was significantly better than men in terms of physical function regardless of the surgical technique used $(p<0.05)$. There was no significant difference between men and women in terms of physical role, pain and general health, social function, emotional role, mental health and fitness / fatigue ( $p>0.05)$. Regardless of the surgical technique used, there was no significant difference between men and women in terms of quality of life in the first postoperative first month ( $p>0.05$ ).

\section{DISCUSSION}

In our study, although the quality of life of the group with off-pump CABG surgery was better than that of the group with on-pump CABG surgery in the first postoperative week, there was no difference between the two techniques in terms of quality of life of the patients in the first postoperative month.

In the study conducted by Immer et al. with 504 patients (on-pump CABG, $n=438$ and off-pump CABG, $\mathrm{n}=66$ ) using the SF-36 form, off-pump CABG patients were significantly better than on-pump CABG patients in physical role/function and emotional role/function after an average of 10.8 months. In this study, it was found that emotional role/function decreased significantly in off-pump CABG patients and physical and emotional role/function in on-pump CABG patients compared to the normal population ${ }^{(7)}$.

Table 1. Comparison of the quality of life between groups one month and one week after coronary bypass surgery.

\begin{tabular}{|c|c|c|c|c|c|c|c|c|}
\hline \multicolumn{4}{|c|}{ Group 2} & \multicolumn{5}{|c|}{ Group 1} \\
\hline & 1.week & 1.month & Point difference & 1.week & 1.month & Point difference & $\mathbf{p}^{1}$ & $\mathbf{p}^{2}$ \\
\hline $\begin{array}{c}\text { Social } \\
\text { function }\end{array}$ & $45(10-100)$ & $70(12.50-100)$ & $22.50(-42.50-60)$ & $67.50(22.50-100)$ & $90(20-100)$ & $10(-80-65)$ & 0.014 & 0.131 \\
\hline $\begin{array}{c}\text { Emotional } \\
\text { role }\end{array}$ & $33.33(0-66.67)$ & $0(0-0)$ & $-33.33(-66.67-0)$ & $33.33(0-100)$ & $0(0-100)$ & $-33.33(-100-33.33)$ & 0.008 & 0.084 \\
\hline $\begin{array}{l}\text { Mental } \\
\text { health }\end{array}$ & $72(16-92)$ & $80(20-96)$ & $4(-20-76)$ & $76(28-100)$ & $84(20-92)$ & $8(-60-64)$ & 0.325 & 0.521 \\
\hline $\begin{array}{l}\text { Fitness/ } \\
\text { Fatigue }\end{array}$ & $45(5-85)$ & $65(20-90)$ & $15(-35-60)$ & $60(20-95)$ & 75 (15-90) & $15(-50-65)$ & 0.073 & 0.992 \\
\hline $\begin{array}{l}\text { Physical } \\
\text { function }\end{array}$ & $20(0-60)$ & 55 (10-90) & $30(0-70)$ & $45(0-70)$ & 75 (30-90) & $25(-5-80)$ & 0.003 & 0.876 \\
\hline $\begin{array}{l}\text { Physical } \\
\text { role }\end{array}$ & $0(0-75)$ & $0(0-0)$ & $0(-75-0)$ & $0(0-100)$ & $0(0-100)$ & $0(-100-100)$ & 0.011 & 0.024 \\
\hline Pain & $32.5(0-100)$ & $77.50(0-100)$ & $22.50(-10-90)$ & $55(10-100)$ & $87.50(20-100)$ & $22.50(-70-90)$ & 0.061 & 0.545 \\
\hline $\begin{array}{l}\text { General } \\
\text { health }\end{array}$ & $60(10-100)$ & 65 (10-95) & $5(-30-45)$ & $60(30-100)$ & $80(50-100)$ & $15(-20-50)$ & 0.695 & 0.073 \\
\hline
\end{tabular}

$p^{1}$ : Comparison of scale scores obtained at the end of the first week between groups

$p^{2}$ : First month as a result of taking the differences of the scale scores obtained at the end of the first week scores comparison of calculated difference scores. 
In the study conducted by Kapetanakis et al. with 191 patients (off-pump CABG, $n=116$ and on-pump CABG, $n=75$ ) using the SF-36 form, there was no difference in terms of quality of life 6 months after on-pump and off-pump CABG. The expected quality of life in patients with multi-vessel coronary artery disease and hypertension was similarly worse in both groups. Six months after CABG, physical component scores of quality of life increased in diabetic patients ${ }^{(8)}$.

In a study conducted by Lindsay et al. in Scotland, the SF-36 questionnaire was applied to 214 patients about 4 weeks before and one year after CABG surgery, and it was determined that there was a significant improvement in the physical role, but less in the physical role of the SF-36 scores of patients who were clinically well postoperatively, ${ }^{(6)}$. Differently, we divided the patients into on-pump and off-pump groups in our study. We did not evaluate the preoperative quality of life with the SF-36 form. When we looked at the difference in one-month and one-week quality of life scores within the on-pump CABG and off-pump CABG groups, we found that the quality of life increased in both surgical techniques.

In the study conducted by Angelini GD, et al., no difference was found between the groups in terms of mortality, morbidity and quality of life due to cardiac causes 6 to 8 years after on-pump CABG and off-pump CABG (9). In the study by Ascione R et al. involving 328 patients (on-pump CABG, $n=159$ and off-pump CABG, $n=169$ ), general and disease-specific quality of life after two to four years postoperatively was similar in both groups (10).

In our study, similar to the above studies, it was found that there was no significant difference between offpump and on-pump CABG one month after surgery in terms of other subscales of quality of life, except for physical role. In our study, unlike these studies, physical function, social function, physical role, emotional role were significantly better one week after the operation in off-pump CABG than in on-pump CABG.

In the study by Herlitz et al., in which they evaluated the quality of life of patients who underwent CABG, they stated that the 3 factors that negatively affect the quality of life 5 years after CABG were female gender, diabetes and chronic obstructive pulmonary disease ${ }^{(11)}$. In our study, regardless of the surgical technique, one week after $C A B G$, physical function was better in the female gender group than in men and one month later, no significant difference was found in the quality of life subscales in both gender groups.

\section{Conclusion}

As a result, although there was a more significant increase in the quality of life of the patients one week after off-pump CABG compared to on-pump CABG, no significant difference was found after one month. One week after CABG, it was determined that physical function was significantly better in women than in men, while there was no significant difference in quality of life in terms of gender after one month. We think that off-pump CABG performed to avoid the negative effects of cardiopulmonary bypass does not significantly contribute to the improvement of the patient's quality of life in the postoperative period. Nevertheless, we think that large-series studies with a much higher number of patients should be conducted in order to obtain a clearer idea on this subject.

Ethics Committee Approval: Approval was obtained from Uludağ University Medical Research Ethics Committee for our study (approval number: 2012-17 / 6)

Conflict of Interest: No conflict of interest was declared by the authors.

Funding: No funding was used for this study.

Informed Consent: Written consent was obtained from all patients participating in the study.

\section{REFERENCES}

1. Yıldırım N, Atalay M. Koroner arter bypass ameliyatı olan hastaların yaşam kalitesinin değerlendirilmesi. Hemşirelik Araştırma Dergisi. 2002;4(1):52-64.

2. Tabakan A, Sokullu O, Sanioğlu S, et al. Atan kalpte ve ekstrakorporal Sirkülasyon kullanılarak yapılan koroner arter cerrahisi ameliyatlarında enflamatuvar yanıtın değerlendirilmesi. Türk Göğüs Kalp Damar Cerrahisi Dergisi. 2006;14(1):24-8. Available from: https://tgkdc.dergisi.org/uploads/pdf/pdf_TGKDC_973. pdf

3. Cooley DA. Con: Beating-heart surgery for coronary revascularisation: is it the most important development since the introduction of the heart-lung machine. Ann ThoracSurg. 2000;70(5):177981.

https://doi.org/10.1016/S0003-4975(00)02052-X

4. Ware JE Jr, Sherbourne CD. The MOS. 36-item short-form health survey (SF-36). I. Conceptual framework and item selection. Med Care. 1992;30(6):473-83. PMID: 1593914.

https://doi.org/10.1097/00005650-199206000-00002

5. Koçyigit H, Aydemir Ö, Fisek G, et al. Kısa Form-36'nın Türkçe versiyonunun güvenilirligi ve geçerliliği. İlaç ve Tedavi Dergisi. 1999;12:102-6. Available from: https://www.researchgate.net/ publication/301799662 
6. Lindsay GM, Hanlon P, Smith LN. Wheatley DJ. Assessment of changes in general health status using the shortform 36 questionnaire one year following coronary artery by-pass grafting. Eur J Cardiothorac Surg. 2000;18(5):557-64. https://doi.org/10.1016/S1010-7940(00)00542-X

7. Immer FF, Berdat PA, Immer-Bansi AS, et al. Benefit to quality of life after off-pump versus on-pump coronary bypass surgery. Ann Thorac Surg. 2003;76(1):27-31. https://doi.org/10.1016/S0003-4975(03)00187-5

8. Kapetanakis El, Stamou SC, Petro KR, et al. Comparison of the quality of life after conventional versus off-pump coronary artery bypass surgery. J Card Surg. 2008;23(2):120-5.

https://doi.org/10.1111/j.1540-8191.2008.00590.x

9. Angelini GD, Culliford L, Smith DK, et al. Effects of on- and off- pump coronary artery surgery on graft patency, survival, and health-related quality of life: Long-term follow-up of 2 randomized controlled trials. J Thorac Cardiovasc Surg. 2009;137(2):295303.

https://doi.org/10.1016/j.jtcvs.2008.09.046

10. Ascione R, Reeves BC, Taylor FC, et al. Beating heart against cardioplegic arrest studies (BHACAS 1 and 2): quality of life at midterm follow-up in two randomised controlled trials. Eur Heart J. 2004;25(9):765-70.

https://doi.org/10.1016/j.ehj.2003.11.015

11. Herlitz J, Brandrup-Wognsen G, Caidahl K, et al. Determinants for an impaired quality of life 10 years after coronary artery bypass surgery. Int J Cardiol. 2005;98(3):447-52.

https://doi.org/10.1016/j.ijcard.2003.11.022 